\title{
Muslim cultural Practices in Nepal
}

\begin{abstract}
:
The purpose of this study is to analyze the cultural practice of Muslims in Nepal. Culture is a shared beliefs, arts, attitudes, values, and socially transmitted behavior patterns of a group or organization. Muslim culture generally includes all the practices which have developed around the religion of Islam, Muslims are rich in culture like other religions in Nepal and they developed a stronger identification with the Nepali state. This paper is based on both primary and secondary data sources followed descriptive method under qualitative approaches.
\end{abstract}

Chompa Mousumi Yasmin

Keywords: Cultural, Islam, Muslim, Nepal, Practices.

Introduction and background of the Study- Muslims are the people who followed or practiced Islam, a monotheistic Abraham religion. Muslims considered that "The Quran is the primary scriptures of Islam; it is Arabic; the unaltered and final revelation of God, Bennett, L. R. (2005). and considered that "the holy book of Muslims, the verbatim word of God as revealed to the Islamic prophet and messenger Muhammad (S.A) The meaning of Muslim is "submitter" (to God) believed that "Islam is the complete and universal version of a primordial faith that revealed many times before through prophets including Adam, Abraham, Moses and Jesus Reeves, J. C. (Ed.). (2004). Islam teaches that" God is merciful, all-powerful, and unique" and guided mankind through prophet revealed scriptures and natural signs Campo, J. E. (2009). Islam teaches about a final judgment where the righteous rewarded in paradise and unrighteous punished in hell. The beliefs of Muslims is that God or Allah is eternal, transcendent and absolutely one incomparable, self-sustaining and neither begets nor was begotten; that.

Muslim philosopher Ibn Arabi said: "A Muslim is a person who has dedicated his worship exclusively to God, Islam means making one's religion and faith God's alone". In a word, it is said that "Muslims are those people who believe that Allah is one and incomparable nothing could compare with him' and Hazraat Mohammad (S.A) is the messenger or prophet of Allah".In Muslim culture there are five basic religious acts, which are considered obligatory for all believers they are creed, daily prayers, almsgiving, fasting during Ramadan, and the pilgrimage to Mecca. With the rapid expansion of the Islami empires, Muslim culture has influenced and assimilated much from the Persian, Egyptian, Caucasian, Turkic, Mongol, South Asian, Malay, Somal, Berber, Indonesian, and Moro cultures. 
Among other religion in Nepal, Muslims religion followed their culture with joy and happiness. Traditionally they followed rich cultural practice.

Historically it is believed that "Islam" is originated in the early 7th century CE in Mecca and by the 8th century the Umayyad Caliphate and extended from Iberia in the west to the Indus River in the east Trofimov, Y. (2008). The Islamic Golden Age refers to the period traditionally dated from the 8th century to the 13th century, during the Abbasid Caliphate, when much of the historically Muslim world was experiencing a scientific, economic and cultural flourishing Peters, F. E., and Watt, W. M. (2003). The expansion of the Muslim world involved various states and dynasties such as the Ottoman Empire, trade and conversion to Islam by missionary activities King, D. A. (1983). The cities of Mecca, Medina and Jerusalem are home to the three holiest sites in Islam" The early forms of Muslim culture formed, from the Rashidun Caliphate to early Umayyad period, predominantly Arab, Byzantine, Persian and Levantine.

In Muslim culture religious concepts and practices included the Five Pillars which are obligatory acts of worship, followed Islamic law (sharia) which touched on virtually every aspect of life and society, from banking and welfare to women and the environment. Islam rejected polytheism and idolatry, called Shirk, and rejected the Christian doctrine of the Trinity. In Islam, God is beyond all comprehension and thus Muslims are not expected to think of him as having a human form. In Muslim culture "God" is described and referred to by certain names or attributes, the most common being Al-Rahmān, meaning "The Compassionate" and Al-Rahìm, meaning "The Merciful". Allāh is traditionally seen as the personal name of God, Other non-Arab Muslims might use different names as much as Allah, for instance "Khod $\bar{a} "$ in Persian or "Kh $\underline{h} u d \bar{a} "$ in Urdu.

A demographic study of 2015 reported that among the global population are $24.1 \%$, Muslims are estimated 1.8 billion Peters, F. E. (2009). Among them 87-90\% are Sunni and 10-13\% are Shia Cohen, B. (2007) small minority Muslim countries are approximately 57 Kogan, M., \& Hawkesworth, M. (2013) and Arabs accounted for around 20\% of all Muslims worldwide Çakmak, C. (Ed.). (2017). The number of Muslims worldwide increased from 200 million in 1900 to 551 million in 1970 Brown, J. (2007) and tripled to 1.6 billion by 2010, Haq, S. N. (2009 ). The majority of Muslims lived in Asia and Africa, Gauvain, R. (2013).

In the Middle East, non-Arab countries such as Turkey and Iran are the largest Muslimmajority countries; the most populous Muslim communities. Countries are Africa, Nigeria and Egypt. Most estimates indicated that the China has approximately 20 to 30 million Muslims (1.5\% to $2 \%$ of the population) Bauer, K. (2015).According to International Population Center to U.S News \& World Report by the San Diego State University' “China 
has 65.3 million Muslims"Imad-ad-Dean Ahmad. (2006). Islam is the second largest religion after Christianity in many European countries, and is slowly catching up to that status in the Americas, with between 2,454,000, according to Pew Forum, and the Council on American-Islamic Relations (CAIR), in the United States Cohen, B. (2007) and the most populous Muslim-majority nation Skyline of Jakarta, capital of Indonesia "approximately 7 million Muslims". Approximately $62 \%$ of the world's Muslims lived in Asia, with over 683 million adherents in Indonesia, Pakistan, India, and Bangladesh .Nepal has 1.164 million Muslims comprising 4.4\% of the total population of Nepal (Table 1) Kathmandu, N. (2014).

The ancestors of Nepali Muslims arrived in Nepal from different parts of South Asia, Central Asia and Tibet during different epochs, and lived amidst the numerically dominant Hindus and Buddhists. About $97 \%$ of the Muslim community lives in the Terai region, while the other $3 \%$ are found mainly in the city of Kathmandu and the western hills. The community numbers 971,056 , about $4.4 \%$ of the total population of Nepal. According to the census of 2011 Nepal, around 1.164 million Muslims in Nepal. Almost all of them lived in Terai Region. The large Muslim concentrations districts are: Rautahat (19.7\%), Banke (19.0\%), Kapilvastu (18.2\%), Parsa (14.5\%), Mahottari (13.3\%), Bara (13.0\%) and Sunsari (11.5\%). There are only 21,866 Muslims in the capital city of Kathmandu $(1.25 \%$ of the total population).

Table 1 .Muslim population growth Census 1971 to Census 2011

\begin{tabular}{|l|l|l|}
\hline Year & Total Muslim Population & Percentage of Muslim Population \\
\hline 1971 & 351156 & $3.0 \%$ \\
\hline 1981 & 399107 & $2.3 \%$ \\
\hline 1991 & 653,055 & $3.5 \%$ \\
\hline 2001 & 971056 & $4.3 \%$ \\
\hline 2011 & $1,164,255$ & $4.4 \%$ \\
\hline
\end{tabular}

Source: Central Bureau of Statistics 1971, 1981 and CBS 2001 and 2011 censuses.

Table 1 shows that the Muslim population growth Census 1971 to 2011where the total Muslim Population are $351156(3.0 \%)$ for the year of $1971 ; 399107(2.3 \%)$ of the total Muslim population for the year of 1981; the total Muslim population for the year of 1991 are $653,055(3.5 \%) ; 971056(4.3 \%)$ of the total Muslim population for the year of 2001 and $1,164,255(4.4 \%)$ of the total Muslim population for the year of 2011. The growth rate of Muslim population has been increases in Nepal. The purposed research study will analyze Muslim cultural practice in Nepal and will discuss Muslim history and categories in Nepal.

History of the Muslims in Nepal: There are different concepts on the beginning of Muslim arrival in Nepal. Some view showed that the entry of Muslim in Nepal begun from seventh 
century onwards, same views showed that during the Lichchavi period there were some Muslim traders in the Kathmandu valley (Regmi, J. C. 1969) were involved in trade with china and Tibet. From the ancient history of Muslim in Nepal informed by Dr, Zahid Parwez a researcher of CERID TU;"there was a state in Simrawangard (presently in Bara districts; one No 2 of Nepal) ruled by a Karnataka ruler Hari Sigh Dev invaded by Giyash Uddin Tuglak the Sultan of Delhi India around 1300 centuries; the King defected and fled from there leaving the state under the invaders. Tuglak army left some senior armies officers to live and ruled over the state of Simrawangard so, they considered the first Muslim resident in Nepal, therefore, the most density of Muslim community are in Bara, Parsa and Rautahat district; after them the kashmiri and Indian Muslims arrived in Nepal; after Suggali treaty a large number of Nepali naïve Muslims population came into Nepal with their own culture ,tradition and customs".

Nepali historians believe that the first Muslims settled in Kathmandu during King Ratna Malla's reign in the late 15th century. Kashmiri traders were probably the first Muslims to arrived, followed by Afghans, Persians and even Arabian (Wikipedia). Ratna Malla's envoy to Lhasa invited Kashmiri Muslims to Kathmandu for trade between Kashmir, Ladakh and Lhasa, also invited Indian Muslims to work as courtiers and counsellors-leading to rivalry with Newar nobles of the Malla courts. As a musicians and specialists on perfumes and ornaments Muslims of Mughal Empire joined their courts.

Historian Baburam Acharya believes that the Muslims were also there to protect King Ratna Malla from rebellious relatives and senior court officials. Like other, the Chaubise Rajas of west Nepal also employed Afghan and Indian Muslims to train Nepali soldiers to use firearms and ammunition. Kashmari Muslims had a great contribution to the unification processes of Nepal so; King Prithvi Narayan Shah encouraged Muslim traders to settle down with their families in Nepal. Historians said that "Prithvi Narayan Shah employed Kashmiri traders as spies and informants due to personal contacts with the Malla rulers". After his victory, he gave them permission to build a mosque named Nepali Jame Masjid, Ghantaghar near Tri-Chandra Campus. During Jang Bahadur Rana's regime, a large number of Muslims migrated to the Tarai in Nepal from India fleeing persecution by the British army during the Sepoy Mutiny in 1857.The Muslims of Nepal are mostly from India but some of them are also found to have come directly from Afghanistan, Persia, Iraq and other Arab countries at later periods.

Categories of Muslim in Nepal: Historically there are three distinct groups of Muslim in Nepal the Tibetan, the Kashmiri and the Madhesi but categorically Muslims of Nepal are divided into different four groups; they are Kashmiri Muslim, Tibetans Muslim, Hilly Muslim and Madhes Muslim. 
Kashmiri Muslims - According to the Vamshavalis, Kashmiri Muslims arrived in Kathmandu during the reign of King Rana Malla (1484-1520 AD). They built a mosque, the Kashmiri Takia, and engaged in different occupations such as scribes to correspond with the Delhi Sultanate, and as scent manufacturers, musicians and bangle suppliers. Some were admitted as courtiers to the Malla durbar, and many traded with Tibet. Speaking language of Kashmiri Muslims are a mixture of Nepali and Urdu. Many Kashmiri Muslims of Kathmandu speaks Newari also. Shah, Sayed, Khawaja, Khan, Pathan, Banu are the community people of Kashmiri Muslim (secondary source).They do not have any particular traditional occupation; most of them are businessman. Kashmiri Muslims are found in different place of Kathmandu valley.

Tibetan Muslim - Muslim migrants of Tibetan origin include both Ladakh and those from Tibetan proper. The latter arrived mostly after the Chinese Communist takeover in 1959 with their language and dress; these Tibetan Muslims are indistinguishable from their Tibetan Buddhist counterparts. Today, many are engaged in the trade of Chinese consumer durables and selling curios. On the whole, this group tends to be more affluent than the other Muslim communities (secondary source). There are no such caste and sub-caste people are found in the community of Tibetan Muslim. They are found in different place of Kathmandu valley but majority are found at Kamalpokhari, Nayabazar, and Lazimpath area of Kathmandu. Most of the Tibetan Muslims are trader and businessman.

Hilly Muslim- A large number of Nepali Muslims lives in different parts of the western hill region, known as mostly in the districts of Gorkha, Tanahun, Kaski, Syangja, Dailekh, Pyuthan, Arghakhanchi, Palpa and Nuwakot. The hilly Muslims are the descendants of Indian migrants, and are synonymously known as churautey (bangle sellers). Mirja, Fakir are the community people of Hilly Muslims. The traditional occupation of them is Bengal seller. Majority of the Hilly Muslims are found in the western Hilly region in Nepal.

Madhesh Muslims - Madhesh Muslims are differs in many aspects from the caste system found among the Madhesi Hindus. Although Muslim groupings are endogamous, and there are elements of hierarchy, there are no religious and ideological principles providing a foundation for the concept of caste; e.g. there is no question of ritual pollution by touching or restriction on interdining, each grouping maintained a separate and distinct identity, especially with regard to intermarriage, Thapa, S. (2010). More than 74 percent of Muslims are found in the Madhesh region. Most of them are farmers, tenants and agricultural labourers.Members of Madhesh-based Muslim communities resided in the Kathmandu valley also, some of them are the leaders of a revival and reform of Islam informed by global Islamist discourses and enabled and promoted by petrodollars and new technologies of communication linking them with Muslims communities around the world Sijapati,. M. 
A. (2011). They provided scholarships for Muslim youth, support for mosques and madras, and religious trainings. The national central organization of Muslims is in the Kathmandu valley and some are at Tarai reign. The ideological influences range of Muslims is the Brotherhood, to Salafism, to the Jamaat-e Islami; Sijapati, M. A. (2012).There are different castes of Muslim people live in Tarai region in Nepal. More than 74 percent of Muslims are found in the Madhesh region in Nepal.

Objective of the study: The objective of this study is to analyze Muslim cultural practice in Nepal, to introduce their history and categories, specially to analyze language, art, literature, major festival like Eid-ul-fitr, Eid-ul-adha, cultural food and deities, dress, etiquette, marriage practice, birth and death ceremony of the Muslim in Nepal.

Research Methods: Descriptive research design has been followed under qualitative approaches to analyze this study and this study is based on both primary and secondary sources of information. Primary information has been taken by face to face interview and telephone conversation with different senior and educated knowledgeable Muslim people who have the full knowledge about the Muslim culture of Nepal in Kathmandu valley also both personal and research experience provided some understanding about uniqueness in the cultural practices of Muslims in Nepal in breadth. Secondary information has been taken from the different Islamic books, journal articles websites. This study has been conducted on the basis of purposive sampling method in Kathmandu valley. Different educated people; district department staff and Cooperative have been purposely selected for this study.

\section{Discussion on Muslim Culture in Nepal}

Language: All Muslims in Nepal generally speaks various local languages but they claim that Urdu as their cultural languages because, all the literature related to Islamic code of conduct available in Nepal written in Urdu language only; they are bound to learn their code of conduct to practice every day cultural life by Dr.Parwez. This research found that Kashmiri Muslim speaks a mixture language of Nepali and Urdu also they fluent in Newari language; Tibetan Muslim speaks Tibetan and Nepali language; Urdu, Awadhi, Bhojpuri, Maithili and Nepali language spoken by the Muslim people of Western or Central or Eastern Madhesh, Dastider, M. (2007).

Literature: The Islamic literature was not available in Nepal some years ago but this study found that various Islamic books are available now in Nepal, especially in the Kathmandu city such as the Holy book Quran, Hadidth, various kinds of Islamic books which are written by Urdu and Nepali language. Translate Quran in Hindi and Nepali is the greatest lasting effect on Islamic literature in Nepal. 
Art: Islamic calligraphy is the artistic practice of handwriting and calligraphy, based upon the alphabet in the lands sharing a common Islamic cultural heritage. It included Arabic Calligraphy, Ottoman, and Persian calligraphy Blair,. S. S. Blair, S., \& Bloom,. J. M. (1995). It is known in Arabic as khatt Islamic, meaning Islamic line, design, or construction Kaestle,J.(2010). Islamic calligraphy developed from two major styles: Kufic and Naskh.Islamic calligraphy incorporated into modern art beginning with the post-colonial period in the Middle East, as well as the more recent style of graffiti. There is no Muslim Arts and Artist found in Nepal.

Architecture: The principal Islamic architectural types for large or public buildings, eg.the Mosque, the Tomb, the Palace and the Fort. From these four types, the vocabulary of Islamic architecture is derived and used for other buildings such as public baths, fountains and domestic architecture (secondary source). Nepal Jame Masjid, Kashmiri Masjid, Iraqui Masjid etc are found as Islamic architecture in Nepal.

Calendar: Muslim calendar consist Muslim events such as Muharram, Sha'ban, Ramadan, Shawwal,Dhu al-Qidahand Dhu al-Hijjah etc. This research found that Nepali Muslims followed the Islamic calendar but Muslim calendar is not followed officially in Nepal due to the majority of Hindu religion. Most of the Muslim countries in the world have holyday on Friday for compulsory weekly prayer but Nepali Muslims did not get this opportunities yet which is most necessary for them. Nepali Muslims had not got any holydays for celebrating their major festival like two Eid before but fortunately, they are getting holyday to celebrate their major festival recently.

Music: Globally, Muslims have had a great influence on music, as it united vast areas under the first caliphs, and facilitated trade between distant lands. Certainly the Sufis, brotherhoods of Muslim mystics, spread their music far and wide. By the secondary source this research found that the Muslim community also earned fame in Nepal as musicians. The Malla rulers regularly brought Indian musicians, dancers, puppeteers and other entertainers, some of whom used to be Muslims, this research also found that some Islamic Gazal, Hamd, Nathe is considered Islamic music.

Festivals: The most important festivals celebrated by Muslims in Nepal are Ramadan, Eidul- Fitar and Eid-ul-Adaha,Eid- Milad-un-Nabi, Moharram, Shab-i-Qadar,Shab-i-Barat etc.Ramadan is the period of one month fasting of Muslim people, which is fallen on the first day of Shawl; Muslim people took foods at the end of Night, before Adan of morning prayer and nothing eat even water all day long; break the fasting (Iftar) hearing the voice(Adan) of evening Prayer. They break their fasting traditionally with dates, fruits, Juice or Sarbat; after Iftar they pray evening prayer (Namaz). Fasting is compulsory for all the 
adult Muslims without children, sick, pregnant, breast feeding women and travelers (secondary source).

Eid is a day of peace and thanks giving; a day of forgiveness and moral victory; a day of good harvest and a day of festive remembrances. Muslim are celebrated two Eid Namely Eid-ul-Fitr and Eid-ul-Adaha.Eid-ul-Fitr are celebrated after one month of fasting (Ramadan) with great joy and happiness; at the day of Eid everyone took bath early in the morning, weared the new cloths, used various perfume or special Itar and go to the Mosque or Eidgah for Eid prayer. Traditionally, Muslim womens art mehendi on their hands in the occasion of Eid. The Eid prayer is most important for all Muslims; along with the prayer Muslims remembered the deceased by prayer for their soul's and salvation, dowa for needy, for grieved, for sick people etc Siddika, (1993). After prayer everyone embraced each other and exchange greeting than meet with friends, relatives, had sweets and various delicious food provided gift to younger, provided foods and money to the poor people on the day of Eid. Providing "Fitr" or Sadaqatul Fitr is compulsory for the Muslims on the day of Eid (secondary source).

Eid-ul-Azaha is called "Bakra Eid" or Eid of sacrifice which followed of the course of Hajj. Globally the Muslim people who completed the Hajj at Makka and who completed the Eid prayer at home sacrificed animals slaughtering (secondary source). This study found that Nepali Muslims also sacrificed animals especially Tarai people sacrificed Goat and Hilly people sacrificed Goat and Buffalo. It is considered good to slaughtering animal at after Eid prayer, but acorroding to the religious law Muslim people could sacrifice animals till to three days of Eid and sacrifice fleash of animal divided into three parts among them one third distributed to the poor another part to the relatives who are unable to give sacrifice animal (Kurbani) and remaining one part of flesh reserved for the family.

Eid-Miladun-Nabi is the birth day of holy Prophet Mohammed (S.A). Culturally some Muslim community of Nepal celebrated this festival; at the day of Eid-Miladun-Nabi people discussed about the life and teachings of the Prophet Mohammed (S.A) Siddika, (1993).It is noted that the birthday celebration is not practiced more in Muslim religion. Maharram is the Death anniversary of Hassan-Husain, grandson of Prophet Mohammed (S.A).Muslims expressed to their sorrows for the death of Husain and keeps fasting 10th day of Maharram. Culturally in Nepal, Tarai Muslims play a special game with sticks on this occasion, Western Hilly Muslims mainly in Gorkha Muslims make Tazia which is made by the bamboos. Muslims of the valley keeps fasting on that day and give alms to the poor. Siddika, (1993).

Shab- i-Meraj is a religious occasion of Muslim it is known as the day of journey of Holy Prophet Hzrat Mohammed (S.A) to the Heaven. Religiously on that day Muslim people 
prayed some extra prayer, read Quran, distributed alms to the poor and discussed the life history of Mohammed (S.A)(secondary source).Muslims all over the the world ce;berated Shab-i-Barat,they awaked up all night and prayed extra prayer, recited Quran, dowa and Durad (Extra prayer or Ibadat) which is preferable to Allah and prophet Mohammed (S.A); It is belief that "Allah wrote the fate of mankind in this night registered all the action of mankind which they performed during the year and recorded the date of death and birth of mankind"(secondary source).

Shab-i-Qadar is very special and sacred occasion for all Muslims in the world, it is known "Lilatul Qadar" and is celebrated during Ramadan month; it is difficult to say the exact date of celebration, generally it is started from the last week or last 10 days of Ramadan but majority said that" the night of $27^{\text {th }}$ of Ramadan is considered Lailatul Qadar or at the night of power. Muslim people prayed extra prayer or Ibadat whole night and distributed money or Zakat to the poor (secondary source)

Food and dietary laws: Culturally Muslims food is very delicious and famous all over the world. In Nepal, Muslims take available food on the basis of local context. Generally they eat, Rice (Bhatt), Lentils (Dal), Spinach (Sagh)Vegetables, Fish, Chicken and Mutton, they take "Ruti" different kinds of Paratha, Chana,fruits Bread, Eggs, Cokies and tea etc at the time of breakfast. Special food are cooked in an especial occasion such as Biryani KheerPolaudifferent items of chicken and Mutton, Meat kebab, Korma, Special achaar and finally served desserts and yogurt. Muslims prepared different kind of delicious food at the time of Iftar; rich people took Dates sweets, Juice or sharbat, fruits, different kinds of pakoda, Chana, various types of desserts etc. Poor people took simple food according to their ability. Special sweets "Sewai"must be made in the occasion of Ramadan and both Eid, Muslims are restricted in their diet, and prohibited foods are included pork products, blood, carrion, and alcohol. Food permissible for the Muslims is known as halal food, they always take Halal meat which is slaughtered by the name of Allah and they do not accept any nonhalal meat from non Muslims without fish and vegetables (secondary source).

Dresses: Religiously and culturally, the dresses or outfits of Muslim women should loose in nature and not overtly display the figure and should cover their head, arms and leg exposed. Muslim women's of Nepal generally wearied a long and loose kurta, suruwal with dopatta and weared saree with long blouse and covered their head. Some areas of Nepal Muslim women wearied the "Borkha" and "Hejab". Tibetan ladies used Tibetan dress with other Muslim dresss. This study found that in some orthodox family women wearied the "Borkha and Hijab" even at the day of their marriage but it is not followed by all Muslim in Nepal it is depend on the social practice of the people of a particular area. Muslim men of Nepal wearied Panjabi, Pajama and Lunge including western dress such as,Vest,Trouzer, Shirt, 
Pants and Coat. Most of the Muslim men wearied Pajama, Panjabi, and wearied Topi at the time of Namaz (prayer)(secondary source).

Etiquette (Aadab ): Aadab, or etiquette is an important practice of Muslim culture. Personal interaction is initiated with the greeting Assalam Waleykum ("peace be with you"), to which the required response is, Wa leykum Assalam ("and with you"). Respect is expressed after a handshake by placing the right hand over the heart. This research study is found that men and women of Muslim community in Nepal do not shake their hands with each other, same-sex conversation, touching, standing or sitting very close are not practiced in Muslim. Muslim people taking leave with the phrase "Khoda Hafez". Differences in age and status are marked through language conventions. Individuals with higher status are not addressed by personal name; instead, a title or kinship term is used. Visitors are always asked to sit and to offer guests to eat something. It is considered improper for a visitor to sit on the floor or ground. In Muslim culture Muslims started food saying "Bismillah" ("in the name of God") before meals, and using only the right hand for eating and drinking and said "Alhamdulillah" ( All praise to Allah) after meal (field study).Islamic hygienic practices mainly fall into the category of personal cleanliness and health. Circumcision of male offspring is practiced in Islam Dahlen, A. (2004).

Marriage: Marriage is a civil contract which consists of an offer and acceptance between two qualified parties in the presence of two witnesses. Marriage performed as the foundation of a Muslim family where required consent of both Muslims bride and groom for the tie to knock. After completing marriage registration religious marriage or Nikah is completed, saying "Kabul" three times. Culturally and religiously the groom is required to pay a bridal gift (Mahr) to the bride Dahlen, A.( 2004).

This research found marriage (Nikah) is almost always an arranged, affair or love marriage is very less among Muslim culture in Nepal but this practice is changing now in Nepali society; Specifically the Muslim people of rural area of Nepal do early marriage but some well educated Muslim family men marry typically around the age of twenty or twenty five and women marry between ages of fifteen or twenty. Muslims allow polygamous marriage, but it depends on a man's ability to support multiple households. Though Dowry is restricted in Islam, most of the Muslim family of Nepal took dowry. Divorce is a source of social stigma, stating "I divorce you"(Talak) three times is considred divorce in Muslim culture, but this concept is not accepted by a very strong and educated family. Generally in a Muslim family, a woman's worked at the home and men's outside the home. However, in practice, this separation is not as rigid as it appears Al-Suwaidi, J.(1995).

Birth and Naming Ceremony: In a Muslim culture the birth of a child is attended with some religious ceremonies. Immediately after the birth, the words of "Adhan"is pronounced 
in the right ear of the child Campo,. J. E. (2009). The parental grandfather asked to name a new born child. The new born child swaddled with a piece of cloths which is belonged to the grandfather. Following Islamic tradition, the head of the child is also shaved, and an amount of money equaling the weight of the child's hair is donated to the poor Nigosian,. S. A. (2004). The naming or the aquiqa ceremony is performed at the seventh day of the birth of child, in which an animal is sacrificed and its meat is distributed among the poor people and Islamic name is given to the child, relatives are invited to the home to celebrate this ceremony (Field study).

Death and the Afterlife: Muslims are believed that after death the soul is judged and moved to the heaven or hell. After the death, the body is appropriately bathed by the members of the same gender and then enshrouded in a threefold white garment called kafan Brief,. A. P., \& Weiss,. H. M. (2002) the nostrils and ears be plugged with cotton, than dead body is taken to the mosque or open field for funeral prayer offered for than taken to the graveyard for burial. Certain religious rites are performed during and after the death of a Muslim where pronounced the Shahada near a dying man as Muslims want their last word to be their profession of faith (field study). In Hilly region some Muslim shaved their head after the death of the member of their family but Tare Muslims did not follow this ritual.

Conclusion: Muslims are rich in culture all over the world as well as in Nepal Muslim people celebrated their culture joyfully with peace and harmony in Nepal, They have their own languge,literature,art, architecture,calendar,music,festival, food and dietary laws, dresses, etiquette, marriage, the birth and death ceremony. Languages spoken by the Muslims of Nepal are Urdu, Awadhi, Bhojpuri, Maithil, Newari, Tibetan and Nepali. Holy Quran and various Islamic books are the literature of Muslim in Nepal; Muslim Arts and Artist are not found in Nepal but Jame Masjid, Kashmiri Masjid, Iraqui Masjid considered as the architecture of Muslim in Nepal. Major festivals of Muslims in Nepal are Ramadan,Eid-ul- Fitar and Eid-ul-Adaha; The food of Nepali Muslim are generally Daal, Bhatt Tarkari but culturally very special food are made by Muslim on their special occasion in Nepal. Muslim peoples always eat Halal meat and followed the prohibited food of Islam. According to the Islamic law Muslims women weried Muslims dress and men wearied western dress along with Muslim dress in Nepal. Assalam Waleykum, Walaikum asalam, Khoda hafiz, Bismillah are considered as Islamic etiquette. Marriage is almost always an arranged, very less love marriage practice are followed by Muslim in Nepal; In Muslim culture, the groom are required to pay a bridal gift $(\underline{m a h r})$ to the bride . Like other religion of Nepal Muslim people also followed their own religious rules on the occasion of birth and death ceremony. 
This research found some cultural differences among the Tarai Muslims and Hill Muslims of Nepal in several ways. The differences are found in physical appearance, language, dress conventions, and cultural practices. The hilly Muslims are very much influenced by the surrounding Hindu culture(secondary source).For the example some Muslims of Hilly region Shaved their head after the death of the member of their family that is the nonMuslim practice totally Siddika,(1993); Head shaving practice are not followed in the Muslim of Tarai region in Nepal.

In brief, Muslims have their distinct identity and culture like other religion in Nepal. Muslims of Nepal still continuing their Islamic culture living in a society of Hindu religion. This article provided a glimpse of cultural practices among the Muslims in Nepal despite of the lack of research and publications on Muslims of Nepal, as they are not in a priority of academics, policy makers and international development partners. I got some available limited books and articles, my understanding of various categories of Muslims in Nepal, i.e. Tibetan, Kashmiri, Hilly and Madhesi Muslims, and also Muslims from around the world. Nevertheless, my desk study and both personal and research experience provided some understanding about uniqueness as well as influence of other religion and cultures in the cultural practices of Muslims in Nepal in breadth. My proposed study will help to know the actual history of Muslim in Nepal and will improve the knowledge about the Muslim culture, and will help to know the differences between cultural practices of Muslim religion from different region in Nepal. To get better understanding of Muslim culture in Nepal in depth, researchers could take this article as a baseline and dwell in depth.

\section{References:}

Abdullah, K., Haque, A., Ahmed, F., \& Shafiq, A. (2019). Towards Devising Islamic Advertising Theory. In Contemporary Management and Science Issues in the Halal Industry (pp. 121137). Springer, Singapore.

A1 Faruqi, L. I. (1987). The Cantillation of the Qur'an. Asian Music, 19(1), 2-25.

Momem .1987, p. 176.

Al-Suwaidi, J. (1995). Arab and western conceptions of democracy. Democracy, war, and peace in the Middle East, 82-115.

Blair, S. S., Blair, S., \& Bloom, J. M. (1995). The art and architecture of Islam 1250-1800 (Vol. 46). Yale University Press.

Bennett, L. R. (2005). Women, Islam and modernity: Single women, sexuality and reproductive health in contemporary Indonesia. Routledge.

Brill.Moghul, Haroon. "Why Muslims Celebrate a Jewish Holiday”. CNN. Retrieved 2018-01-18.

Britannica, E. (2004). Encyclopcedia Britannica Online. Britannica Online.

Brown, J. (2007). The Canonization of al-Bukhārī and Muslim The Formation and Function of the Sunni Hadìth Collection.

Bauer, K. (2015). Gender Hierarchy in the Qur'ān: Medieval Interpretations, Modern Responses. Cambridge University Press. 
Brief, A. P., \& Weiss, H. M. (2002). Organizational behavior: Affect in the workplace. Annual review of psychology, 53(1), 279-307.

Cavendish, M. (2011). Illustrated Dictionary of the Muslim World. New York: Marshall Cavendish Corp.https://www.everyculture.com/A-Bo/Bangladesh.htm.

Campo, J. E. (2009). Encyclopedia of Islam. Infobase Publishing.

Çakmak, C. (Ed.). (2017). Islam: A Worldwide Encyclopedia. ABC-CLIO.

CIA, C. (2011). The World Factbook. Central Intelligence Agency.

Cohen, B. (2007). Kingship and colonialism in India's deccan 1850-1948. Springer.

Dahlen, A. (2004). Islamic Law, Epistemology and Modernity: Legal Philosophy in Contemporary Iran. Routledge.

Dickinson, E. (2002). Ibn al-Salah al-Shahrazuri and the Isnad. JOURNAL-AMERICAN ORIENTAL SOCIETY, 122(3), 481-505.

Dastider, M. (2007). Understanding Nepal: Muslims in a plural society. Har Anand Publications.

Esposito, J. L. (1998). Islam: The straight path (Vol. 165). New York: Oxford University Press.

Gauvain, R. (2013). Salafi Ritual Purity: In the Presence of God. Routledge.

Gardet, L., \& Jomier, J. Islam, I Definition and Meaning. Encyclopaedia of Islam .

Hidayatullah, A. A. (2014). Feminist Edges of the Qur'an. Oxford University Press, US.

Haq, S. N. (2009). Science in Islam. Islam \& Science, 7(2), 151-159.

Halabi, A., \& Brown, J. A. (2009). Constitution of Medina. The Oxford Encyclopedia of the Islamic World.

Imad-ad-Dean Ahmad. (2006). Signs in the Heavens: A Muslim Astronomer's Perspective on Religion and Science. Amana Publications.

Joseph, S., \& Nağmābādī, A. (Eds.). (2003). Encyclopedia of women and Islamic

cultures: Family, law and politics (Vol. 2). Brill.

Kogan, M., \& Hawkesworth, M. (2013). Encyclopedia of Government and Politics: 2-volume set.

King, D. A. (1983). The astronomy of the Mamluks. Isis, 74(4), 531-555.

Kathmandu, N. (2014). Central Bureau of Statistics. Population (in million), 33, 34-0.

Leaman, O. (Ed.). (2006). The Qur'an: an encyclopedia. Routledge.

Lapidus, I. M. (2002). A history of Islamic societies. Cambridge University Press.

Meri, J. W. (Ed.). (2005). Medieval Islamic civilization: an encyclopedia. Routledge.

Nigosian, S. A. (2004). Islam: Its history, teaching, and practices. Indiana University Press.

Peters, F. E. (2009). Islam: A guide for Jews and Christians. Princeton University Press.

Quataert, D. (2005). The Ottoman Empire, 1700-1922. Cambridge University Press.

Reeves, J. C. (Ed.). (2004). Bible and Qur'ān: Essays in scriptural intertextuality (Vol. 24).

Rahman, F. (1983). Some key ethical concepts of the Qur'ān. The Journal of Religious Ethics, 170-185.

Regmi, J. C. (1969). Lichchavi Sanskriti. Kathmandu: Ratna Pustak Bhandar, BS, 2036, 150.

Saritoprak, Z., \& Griffith, S. (2005). Fethullah Gülen and the 'People of the book': a voice from Turkey for interfaith dialogue. The Muslim World, 95(3).

Saliba, G. (1994). Early Arabic critique of Ptolemaic cosmology: A ninth-century text on the motion of the celestial spheres. Journal for the History of Astronomy, 25(2), 115-141.

Sijapati, M. A. (2012). Islamic revival in Nepal: religion and a new nation (Vol. 45). Routledge. 
Siddika,S. (1993). Muslims of Nepal .Kathmandu,Nepal.

Trofimov, Y. (2008). The Siege of Mecca: The 1979 Uprising at Islam's Holiest Shrine. Anchor.

Thapa, S. (2010). Caste Hierarchy: The inter-Ethnic Stratification in the Muslim society of Nepal. Tribhuvan University Journal, 18(1).

Watt, W. M. (1998). Islam and the Integration of Society (Vol. 2). Psychology Press.

https://core.ac.uk/download/pdf/15605085.pdf

\section{Works Cited}

Baker II, Bruce P.. “O Pioneers!The Problem of Structure.”Great Plains Quarterly, vol. 2, no. 4, Fall 1982, pp. 218-23.

Cather, Willa. O Pioneers! ICON Group International, Inc., 2005.

Glotfelty, Cheryll. "Introduction: Literary Studies in an Age of Environmental Crisis." The Ecocriticism Reader: Landmarks in Literary Ecology. Eds. CheryllGlotfelty and Harold Fromm.The University of Georgia Press, 1996, pp. XV-XXXVII. Print

Gustafson, Nell. "Getting Back to Cather's Text: The Shared Dream in O Pioneers!"Western American Literature, vol. 30, no. 2, Summer 1995, pp. 151-62.

Hannigan, John. "Environmental Discourse."Environmental Sociology.Reprint.Routledge, 2008, pp. 37-52. Print.

Harold Fromm.The University of Georgia Press, 1996, pp. XV-XXXVII. Print

Jamieson, Dale. "Justice: The Heart of Environmentalism." Environmental Justice and Environmentalism: The Social Justice Challenge to the Environmental Movement. Eds. Ronald Sandler and Phaedra C. Pezzullo.The MIT Press, 2007. 85-101

Leopold, Aldo. Sand County Almanac. Oxford UP, 1949.

Logie, John. "Homestead Act: Rhetoric and Property in the American West and the World Wide Web." Rhetoric Society Quarterly, vol. 32, no. 3, Summer 2002, pp. 33-59.

Muir, John. "A Wind-Storm in the Forests."Literature and the Environment: A Reader on Nature and Culture. Eds. Lorraine Anderson, Scott Slovic and John P. O'Grady. Longman, 1999, pp. 78-84. Print

O'Brien, Sharon. "The Unity of Willa Cather's "Two-Part Pastoral": Passion in O Pioneers!" Studies in American Fiction, vol. 6, no. 2, Autumn 1978, pp. 157-71.

Pepper, David. "Utopanism and Environmentalism."Environmental Politics, vol. 14, no. 1, Feb., 2005, pp. 3-22

Roark, James L. "George W. Julian: Radical Land Reformer." Indiana Magazine of History, vol. 64, no. 1, March 1968, pp. 25-38.

Rolston III, Holmes. "Value in Nature and the Nature of Value."Environmental Ethics.Eds. Andrew Light and Holmes Rolston III. Blackwell, 2003, pp. 143-53.

Sanders, Scott Russell.“Speaking a Word for Nature."The Ecocriticism Reader: Landmarks in Literary Ecology. Eds. CheryllGlotfelty and Harold Fromm. The University of Georgia Press, 1996, pp. 182-95. Print 